\section{Scientific journal}

PHYSICAL AND MATHEMATICAL EDUCATION

Has been issued since 2013.

Науковий журнал

ФІЗИКО-МАТЕМАТИЧНА ОСВІТА

Видається $з 2013$.
ISSN 2413-158X (online)

ISSN 2413-1571 (print)

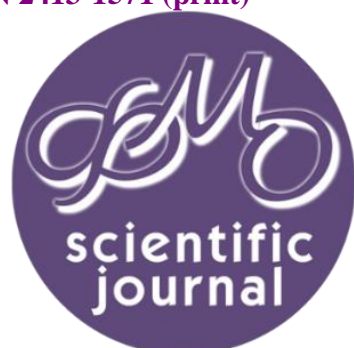

Бугра А.В. Технологічні аспекти індивідуалізації самостійної навчальної діяльності студентів у процесі вивчення вищої математики. Фізико-математична освіта. 2021. Випуск 2(28). С. 29-33.

Buhra A. Technological aspects of students' independent learning activity individualization in the process of studying higher mathematics. Physical and Mathematical Education. 2021. Issue 2(28). P. 29-33.

DOI 10.31110/2413-1571-2021-028-2-005

Удк 378.147.091.31-059.1

A.B. Бугра

Криворізький національний університет, Україна alina.bugra@knu.edu.ua

ORCID: 0000-0003-3978-3404

\title{
ТЕХНОЛОГІЧНІ АСПЕКТИ ІНДИВІДУАЛІЗАЦІЇ САМОСТІЙНОЇ НАВЧАЛЬНОЇ ДІЯЛЬНОСТІ СТУДЕНТІВ У ПРОЦЕСІ ВИВЧЕННЯ ВИЩОЇ МАТЕМАТИКИ
}

Формулювання проблеми. В умовах інтенсивного зростання інформації процес формування професійних якостей та здібностей майбутніх фахівців повинен відбуватися впродовж життя. Неперервне навчання $\epsilon$ системоутворюючим компонентом освітньої парадигми європейських країн. У цьому контексті самостійна робота студентів, як важлива форма освітнього процесу, повинна стати його безпосередньою основою. Проблема постає більш значущою для студентів закладів вищої освіти технічного профрілю, ураховуючи прискорений розвиток науки, техніки й технологій. Це, водночас, актуалізує проблему вдосконалення самостійної їхньої навчальної діяльності, одним із шляхів вирішення якої ми вбачаємо саме в ії індивідуалізації.

Матеріали і методи. Використано досвід автора щодо реалізації та забезпечення прочесу індивідуалізації самостійної навчальної діяльності студентів під час викладання вищої математики. здійснено аналіз науково-педагогічної та науковометодичної літератури.

Результати. У статті розкрито основні технологічні аспекти індивідуалізації самостійної навчальної діяльності студентів у закладах вищої світи технічного профілю шляхом сприйняття ними лекційного матеріалу та семінарськопрактичних занять з математики. Обгрунтовано алгоритм використання під час лекційних занять технології, представленої у вигляді «Інтелект-карти», що сприяє розвитку здатності студентів до творчого використання результатів навчання.

Висновки. Аналіз ефективності індивідуалізації самостійної навчальної діяльності студентів доводить необхідність ії застосування в прочесі вивчення математичних дисциплін. Проте, викладені методи не вичерпують весь спектр можливостей викладача. Розширення діапазону методичних прийомів та визначення їх дидактичних можливостей ми розглядаємо як один із векторів подальших дослідницьких пошуків.

КлючОВІ СловА: індивідуалізація навчання, самостійність, технологія «Інтелект-карта», лекція, студенти закладів вищої освіти технічного профілю.

\section{ВСТУП}

Постановка проблеми. Глобальні соціально-економічні та широкомасштабні науково-технічні інновації початку третього тисячоліття стимулюють переорієнтацію світової освітньої системи з моделі "освіта на все життя» до моделі «освіта протягом усього життя». Адже якщо ще кілька десятиліть тому людина мала можливість протягом професійної діяльності використовувати майже без змін систему знань, умінь і навичок, то бурхливий розвиток науки і техніки, швидке проникнення інформаційних технологій у всі галузі сучасної людської діяльності вимагають формування у випускника закладу вищої освіти технічного профілю не тільки системи знань та умінь, що становлять основу фахової підготовки, а й розвитку готовності до постійного самостійного здобування знань, необхідних для професійного зростання, саморозвитку та самовдосконалення. Ці стратегічні суспільні запити скеровують сучасну вищу технічну школу на оновлення системи самостійної навчальної діяльності студентів, яка б забезпечувала майбутнім фахівцям технічних спеціальностей можливість здобувати фундаментальні знання, професійні вміння, сприяла формуванню готовності до самоосвіти, розвивала здатність до творчого використання ії результатів. 
Аналіз останніх публікацій. На тлі суспільних пріоритетів, коли ініціативність, самостійність, творча активність почали визначатися провідними рисами особистості, питання оновлення форм і методів самостійної роботи суб'єктів навчання різнобічно досліджувалися в дидактиці вищої школи (Ю. Атаманчук, В. Буряк, Н. Ванжа, О. Василенко, О. Коновал, А. Кузьмінський, О. Малихін, М. Солдатенко, Т. Фіногеєва, А. Чиж та ін.). У пошуку шляхів підвищення якості самостійної роботи учнів загальноосвітньої і студентів вищої школи на засадах особистісно зорієнтованого підходу вчені Г. Васьківська, І.Дорохіна, Н. Жукова, О. Костіна, І. Малафіїк, Л. Образцова, О. Пінська, Г. Романова, Г. Терещук, М. Чобітько, І. Шайдур, О. Ярошенко окреслили, як дієвий засіб, диференціацію та індивідуалізацію навчальної діяльності загалом, і самостійної навчально-пізнавальної діяльності як ії невід'ємної складової зокрема. У напрямі вдосконалення самостійної навчальної роботи з урахуванням особливостей вивчення студентами природничо-математичних дисциплін у закладах вищої освіти технічного профілю значного поштовху надали наукові пошуки О. Королюка, А. Меняєва, А. Цюприка.

Метою статті $є$ обґрунтування технологічних аспектів індивідуалізації самостійної навчальної діяльності студентів у процесі вивчення вищої математики.

\section{РЕЗУЛЬТАТИ ДОСЛІДЖЕННЯ}

Індивідуалізація самостійної навчальної діяльності (далі - СНД) студентів розпочинається на етапі підготовки до лекції і продовжується в аудиторії під час сприйняття ними лекційного матеріалу. Як і педагоги-науковці (Мороз, Падалка, Юрченко, 2003), вважаємо, що стимул до самостійної роботи студентів створюється не простим закликом наполегливо працювати, а характером викладу навчального матеріалу, особливістю методів проведення лекцій. Так, мотивуючи студентів до СНД на початку тематичної лекції, викладач робить огляд літератури, надає студентам рекомендації щодо змісту та методів самостійного опрацювання навчального матеріалу, роз'яснює його особливості та труднощі, які можуть при цьому виникнути. У сенсі індивідуалізації особливі можливості мають вступні й настановчі лекції, а також їх різновиди, які мають значний потенціал розвитку індивідуальних особливостей студентів, зокрема це:

- проблемна лекція, на якій після самостійного опрацювання навчального матеріалу студенти висловлюють власні гіпотези та методи вирішення проблеми (розв'язку задачі), шляхи перевірки отриманих результатів, можливості їх практичного використання.

- лекція-конференція, у процесі якої студенти виступають із самостійно підготовленими доповідями, рефератами, розв'язками оригінальних задач, доведенням теорем, які виходять за межі навчальної програми математичної підготовки у закладах вищої освіти технічного профілю.

Різновидом лекції-конференції є лекція-прес-конференція. У процесі дослідно-експериментальної роботи остання проводилася, наприклад, за темою «Визначений інтеграл. Формула Ньютона-Лейбніца», підготовка та участь у якій поставала дієвим засобом розвитку готовності студентів усіх типологічних груп до самостійної навчальної діяльності. У процесі підготовки до заняття студентам пропонувалося детально опрацювати конспекти попередніх лекцій та джерела інформації, рекомендовані викладачем для самостійного вивчення нової теми. У вступній частині лекції, після оголошення теми, викладач пропонував студентам самостійно підготувати й письмово задати йому запитання за цією темою. Протягом 5-10 хвилин студенти переглядали попередньо опрацьовані матеріали та конспекти і формулювали запитання, найбільш цікаві та складні для них. Далі викладач сортував запитання і в залежності від дидактичної ситуації та підготовки аудиторії вибиралися варіанти проведення лекції, зокрема, такі:

1. На запитання студентів відповідає викладач або найбільш підготовлені студенти групи.

2. Лектор сортує запитання, викладає матеріал, акцентуючи увагу на запитаннях, самостійно дібраних студентами. Значний дидактичний потенціал має лекція-консультація, проведення якої здійснюється викладачем або студентами. Загальними психолого-педагогічними вимогами до лекцій такого типу визначаємо:

- уважне ставлення до висловлених студентами труднощів;

- створення ситуації успіху;

- створення ситуації взаємного навчання, інтелектуального взаємозбагачення;

- позитивну оцінку досягнень студентів у самостійній навчальній діяльності.

Лекція з раніше запланованими помилками активізує мисленнєву діяльність студентів, уміння аналізу ситуації, узагальнення висновків, орієнтує їх на використання умінь аргументації власної точки зору. Так, наприклад, вона проводилася за темою «Вектори, дії над ними. Скалярний добуток векторів». Студентам попередньо пропонувалося завдання самостійно ознайомитися та законспектувати матеріал лекції за джерелами інформації, рекомендованими викладачем. У вступній частині лекції, після оголошення теми, студентам повідомлялося, що в лекції навмисне будуть зроблені помилки різних видів - логічні та у визначенні понять. У процесі викладання ці помилки сплановано допускалися, а студенти по ходу проведення лекції ці помилки з'ясовували, відзначали у конспекті, порівнювали 3 самостійно законспектованим матеріалом, пояснювали їх сутність. За 20-25 хвилин до закінчення лекції організовувалося обговорення та виправлення допущених помилок. Результати цієї роботи засвідчують, що такий метод проведення лекції окрім дидактичного ефекту сприяє формуванню позитивної мотивації до самостійної навчальної діяльності, активізує уміння цієї діяльності (особливо уміння аналізувати), дозволяє поглибити та закріпити математичні знання.

Лекція з елементами мікровикладання передбачає залучення студентів групи до презентації навчального матеріалу, самостійно опрацьованого і структурованого, та вкрапленого в лекцію викладача на засадах дидактичної контамінації.

Студентам пропонувалося в 5-7 хвилинній доповіді:

- висвітлити перспективність та практичну значущість для професійної діяльності фахівців інженерних спеціальностей окремої теми чи розділу математики;

- зробити огляд літератури за темою;

- надати коротку історичну довідку «3 життя творців математичної науки»; 
- доповнити обов'язковий навчальний матеріал додатковою інформацією, отриманою у процесі самостійного опрацювання літератури.

Доцільною при проведенні лекційних занять з математики є індивідуалізація самостійної навчальної діяльності студентів з використанням технології локбука - записника, у якому студенти, аналізуючи тези лектора, нотують на полях конспектів або у спеціальному окремому зошиті власні ідеї, роздуми, ускладнення, запитання, які виникли у процесі сприйняття навчального матеріалу, і постають підґрунтям подальшого самостійного осмислення та опрацювання. Технологія локбука спрямована на відпрацювання навичок самоаналізу, самооцінки, розвиток рефлексивних дій, що особливо важливо для студентів із завищеною або заниженою оцінкою результатів СНД.

Результативним методом індивідуалізації самостійної навчальної діяльності студентів при підготовці до лекційних та семінарсько-практичних занять з математики та в їх проведенні постають також інтелектуальні технології у вигляді «Інтелект-карти» (mind map). При перекладі цього англійського терміна можна зустрітися з декількома варіантами, як-от: «карта пам'яті», «карта думки», «карта розуму», «інтелект-карта», «ментальна карта», «концентр-карта», «асоціативна карта», але найпоширенішим варіантом є використання терміну «інтелект-карта» (Бирка, 2013).

Дидактичне призначення «Інтелект-карт» у процесі вивчення вищої математики полягає в навчанні студентів ефективному накопиченню самостійно опрацьованої інформації, її аналізі, трансформації, узагальненні, візуалізації отриманих результатів у вигляді презентації багаторівневої схеми з вузлами, гілками і взаємозв'язками (Бугра, 2014, 2016). Якщо карта готується в електронному вигляді, то в процесі її презентації суб'єкти навчання можуть доповнювати та редагувати ії структуру.

Навчання студентів картографуванню в процесі вивчення вищої математики має досить значний дидактичний ефект щодо розвитку вмінь самостійної навчальної діяльності. Зазначимо, що це особливо важливо для студентів закладів вищої освіти технічного профілю, які в процесі навчання повинні розвивати наочно-образне та логічне мислення, бо на початковому етапі складання «Інтелект-карт» навчаємо студентів алгоритму картографування.

Варто підкреслити, що структурування та візуалізація самостійно опрацьованого студентами матеріалу сприяє його систематизації, а тому й більш глибокому засвоєнню. Інтелект-карти дозволяють графічно представити навчальну інформацію, що допомагає чіткіше визначити, зрозуміти та запам'ятати ключові математичні поняття і зв'язки між ними. Таке розміщення навчального матеріалу є зручною формою структуризації інформації у візуальній формі, і засвоєне в процесі самостійної навчальної діяльності під час вивчення вищої математики може бути «перенесене» на вивчення інших навчальних дисциплін та самостійну навчальну діяльність загалом.

Слід також урахувати, що при використанні Інтелект-карт в самостійній навчальній діяльності, крім абстрактнологічного мислення, властивого лівій півкулі головного мозку людини, спрацьовує образне світобачення, за яке відповідає права півкуля мозку. Таким чином, доцільний як з дидактичного, логічного, так і з естетичного погляду виклад навчального матеріалу, сприяє його кращому сприйняттю, запам'ятовуванню та осмисленню, викликає у студентів відчуття впевненості у своїх силах, сприяє підвищенню мотивації до самостійного опрацювання навчального матеріалу, що $є$ особливо актуальним для студентів з високим рівнем готовності до СНД (Бугра, 2014, 2016).

У процесі роботи з Інтелект-картою були виявлені та апробовані варіанти забезпечення індивідуального підходу до студентів у процесі їх самостійної навчальної діяльності:

Bapiaнm 1. Інтелект-карта може використовуватися як засіб планування самостійної навчальної діяльності студента у процесі вивчення конкретної дисципліни. Цей засіб індивідуалізації особливо ефективний для студентів групи, які мають проблеми з плануванням, організацією та вибором методів СНД. Інтелект-карта теми містить основні етапи вивчення теми та навчальну інформацію, яку студент має засвоїти в конкретні терміни.

Варіант 2. Запропонована заздалегідь інтелект-карта лекції по математиці значно підвищує ефективність СНД студентів усіх типологічних груп на занятті, адже весь зміст теоретичного матеріалу є структурованим, наочним та логічно пов'язаним.

Варіант 3. На етапі завершення лекційного заняття підведення підсумків з використанням «Інтелект-карти» дозволяє більш плідно узагальнити навчальний матеріал, акцентувати увагу студентів на тій інформації, яку необхідно більш поглиблено самостійно опрацювати. Студентам бажано також запропонувати доповнення карти гілками чи елементами після опанування навчального матеріалу, запропонованого викладачем для самостійного вивчення.

Варіант 4. Студентам можна пропонувати:

а) завдання випереджувального чи узагальнювального характеру на картографування теми чи розділу вищої математики;

б) консультування однокурсників за конкретною темою з використанням власноруч складеної «Інтелект-карти»;

в) проведення міні-лекції («вкраплення» в лекцію викладача з презентацією «Інтелект-карти»);

г) здійснення самоаналізу та оцінки власної «Інтелект-карти» чи складеної іншими студентами.

Bapiaнm 5. Студентам можна рекомендувати використовувати «Інтелект-карти» при складанні плану відповідей на семінарсько-практичних заняттях.

Варіант 6. а) використання «Інтелект-карти» як орієнтира при визначенні головного в самостійній навчальній діяльності; б) використання «Інтелект-карти» у самостійній роботі під час підготовки до заходів контрольного характеру (контрольних робіт, колоквіумів, заліків, іспитів) студентам усіх типологічних груп.

У результаті виконання індивідуальних завдань по створенню «Інтелект-карт» суб'єкти навчальної діяльності формують індивідуальний план їх побудови, що надає навчальному процесу творчого характеру, сприяє інтелектуальному розвитку студента та його самореалізації. Це особливо важливо для тих суб'єктів навчальної діяльності, хто має занижену самооцінку, недостатній рівень сформованості умінь СНД та невпевнений у власних силах. 


\section{ВИСНОВКИ ТА ПЕРСПЕКТИВИ ПОДАЛЬШОГО ДОСЛІДЖЕННЯ}

Отже, ми дійшли висновку, що за індивідуалізації самостійної навчальної діяльності студентів у процесі вивчення вищої математики вони можуть безпосередньо отримати поради та індивідуальні рекомендації у процесі:

- обміну інформацією, коли студенти обмінюються нею з теоретичного питання чи розв'язками задач;

- повністю самостійного пошуку відповіді на запитання. Цінним у цьому випадку $є$ те, що студент вчиться аналізувати найбільш актуальну інформацію, критично їі оцінювати, структурувати та використовувати;

- участі у діяльності віртуальних класів чи лабораторій, синхронних і відстрочених телекомунікацій;

- залучення до самостійного оволодіння інтерактивним курсом з програмного чи позапрограмного курсу математики.

Для забезпечення ефективності індивідуалізації самостійної навчальної діяльності студентів у процесі вивчення вищої математики викладач може створити сторінку підтримки свого аудиторного курсу, де студенти зможуть самостійно знайти додаткову інформацію, інструкцію щодо розв'язання типових задач чи більш складних завдань. При цьому бажаним має бути зворотній зв'язок, щоб студенти могли в будь-який час встановити контакт з викладачем чи між собою. Організація індивідуалізації самостійної навчальної діяльності студентів пов'язана також з особливостями побудови освітнього курсу та специфікою історії математики як науки. Тому, ефективна організація такого навчання, що доповнює традиційну лекційно-практичну систему, підвищує його результативність, сприяє інтелектуальному розвитку та творчій активності студентів, стимулює їх науково-дослідницьку роботу. Перспективи подальших розвідок вбачаємо у науковому обґрунтуванні форм та методів підвищення професійної компетентності викладачів закладів вищої освіти технічного профілю у галузі індивідуалізації навчання, бо саме від їхньої майстерності залежить рівень навчальної мотивації студентів.

\section{Список використаних джерел}

1. Мороз О. Г. Педагогіка і психологія вищої школи: [навч. посіб.] / О. Г. Мороз, О. С. Падалка, В. І. Юрченко / ред. О. Г. Мороз. Київ : НПУ, 2003. 267 с.

2. Бирка Маріан. Теоретико-методичні основи використання інтелектуальних технологій у професійній діяльності вчителів природничо-математичних дисциплін. Нова педагогічна думка : науково-методичний журнал. 2013. № 3 (75). C. 3-6.

3. Бугра А. В. Дидактичні можливості методу «Інтелект-карт» при вивченні вищої математики у вищих технічних навчальних закладах. Дистанційне навчання в контексті розвитку синергетичного мислення: матеріали Всеукраїнської науково-практичної конференції з міжнародною участю (м. Херсон, 30 - 31 жовтня 2014 року) / Наук. ред. Юзбашева Г. С. Херсон : Айлант, 2014. Випуск 17. С. 153-155.

4. Бугра А. В. «Інтелект-карти» як засіб індивідуалізації самостійної навчальної діяльності студентів при вивченні вищої математики. Проблеми модернізації змісту і організації освіти на засадах компетентнісного підходу : матеріали міжнародної науково-методичної конференції (м. Харків, 27 - 28 листопада 2014 року). Харків: ХНАДУ, 2014. С. 344348.

5. Бугра А. В. Варианты индивидуализации самостоятельной учебной деятельности студентов с использованием интеллект-карт. International Scientific Review of the Problems and Prospects of Modern Science and Education. International Scientific Review. № 1 (11). 2016. P. 92-94.

\section{References}

1. Moroz O. H., Padalka O. S., Yurchenko V. I. (2003). Pedahohika i psykholohiia vyshchoi shkoly [Pedagogy and psychology of high school]: [navch. posib.] / red. O. H. Moroz. Kyiv : NPU. 267 [in Ukrainian].

2. Byrka Marian. (2013). Teoretyko-metodychni osnovy vykorystannia intelektualnykh tekhnolohii u profesiinii diialnosti vchyteliv pryrodnycho-matematychnykh dystsyplin. Nova pedahohichna dumka : naukovo-metodychnyi zhurnal [New pedagogical thought: scientific and methodical journal]. № 3 (75). 3-6 [in Ukrainian].

3. Buhra A. V. (2014). Dydaktychni mozhlyvosti metodu «Intelekt-kart» pry vyvchenni vyshchoi matematyky u vyshchykh tekhnichnykh navchalnykh zakladakh. Dystantsiine navchannia $v$ konteksti rozvytku synerhetychnoho myslennia [Distance learning in the context of the development of synergetic thinking]: materialy Vseukrainskoi naukovo-praktychnoi konferentsii z mizhnarodnoiu uchastiu (m. Kherson, 30 - 31 zhovtnia 2014 roku) / Nauk. red. Yuzbasheva H. S. Kherson : Ailant. Vypusk 17. 153-155[in Ukrainian].

4. Buhra A. V. (2014). "Intelekt-karty» yak zasib indyvidualizatsii samostiinoi navchalnoi diialnosti studentiv pry vyvchenni vyshchoi matematyky. Problemy modernizatsii zmistu i orhanizatsii osvity na zasadakh kompetentnisnoho pidkhodu [Problems of modernization of the content and organization of education on the basis of the competence approach]: materialy mizhnarodnoi naukovo-metodychnoi konferentsii (m. Kharkiv, 27 - 28 lystopada 2014 roku). Kharkiv: KhNADU. $344-348$ [in Ukrainian].

5. Buhra A. B. (2016). Varianty individualizacii samostoyatel'noj uchebnoj deyatel'nosti studentov s ispol'zovaniem intellekt-kart. International Scientific Review of the Problems and Prospects of Modern Science and Education. International Scientific Review. № 1 (11). P. 92-94 [in Russian]. 


\section{TECHNOLOGICAL ASPECTS OF STUDENTS' INDEPENDENT LEARNING ACTIVITY INDIVIDUALIZATION IN THE PROCESS OF STUDYING HIGHER MATHEMATICS}

\section{Alina Buhra}

Abstract.

Kryvyi Rih National University, Ukraine

Problem formulation. In the conditions of rapid growth of information the process of professional qualities formation and abilities of future specialists should take place during life. Continuing education is a system-forming component of the educational paradigm of European countries. In this context, the independent work of students, as an important form of educational process must become its basis. The issue is becoming more significant for students of higher education institutions of technical profile taken into consideretion the rapid development of science, technology and engineering. This, at the same time, actualizes the problem of improving independent learning activities, one of the ways to solve which we consider in its individualization.

Materials and methods. The author's experience in implementing and ensuring the process of individualization of students' independent learning activities during the teaching of higher mathematics is used. The analysis of scientific-pedagogical and scientific-methodical literature is carried out.

Results. The main technological aspects of students' independent learning activities individualization in higher education institutions of technical profile by their perception of lecture material and tutorial-practical classes in mathematics are considered in the article. The algorithm of using the technolog presented in the form of "Mind map" during lectures which promotes the development of students' ability to apply learning outcomes creatively is reasoned.

Conclusions. Analysis of the effectiveness of students' independent learning activities individualization proves the need for its application in the study of mathematical disciplines. However, the above methods do not highlight the full range of tutor' spossibilities. We consider the expansion of the range of methodological techniques and their didactic possibilities definition as one of the vectors of further research.

Key words: learning individualization, independence, "Mind map" technology, lecture, students of higher education institutions of technical profile. 